\title{
THE TRANSMISSION MECHANISM AND THE ROLE OF ASSET PRICES IN MONETARY POLICY
}

\author{
Frederic S. Mishkin \\ Working Paper 8617 \\ http://www.nber.org/papers/w8617 \\ NATIONAL BUREAU OF ECONOMIC RESEARCH \\ 1050 Massachusetts Avenue \\ Cambridge, MA 02138 \\ December 2001
}

Prepared for the Oesterrische Nationalbank conference on "The Monetary Transmission Mechanism," November 9, 2001. The views expressed herein are those of the authors and not necessarily those of the National Bureau of Economic Research.

(C) 2001 by Frederic S. Mishkin. All rights reserved. Short sections of text, not to exceed two paragraphs, may be quoted without explicit permission provided that full credit, including (C) notice, is given to the source. 
The Transmission Mechanism and the Role of Asset Prices in Monetary Policy

Frederic S. Mishkin

NBER Working Paper No. 8617

December 2001

JEL No. E52, E40

\begin{abstract}
This paper surveys the transmission mechanisms of monetary policy beyond the standard interest rate channel by focusing on how monetary policy affects the economy through other asset prices. It outlines how the monetary transmission mechanisms operating through stock prices, real estate prices, and exchange rates affect which affect investment and consumption decisions of both firms and households. Given the role that asset prices play on the transmission mechanism, central banks have been often tempted to use them as targets of monetary policy. This paper shows that despite the significance of asset prices in the conduct of monetary policy, targeting asset prices by central banks is likely to lead to worse economic outcomes and might even erode the support for their independence.
\end{abstract}

Frederic S. Mishkin

Graduate School of Business

Uris Hall 619

Columbia University

New York, NY 10027

and NBER

fsm3@columbia.edu 
Although the instrument set by monetary policymakers is typically an interest rate, monetary policy affects the economy through other asset prices besides those on debt instruments. Thus, movements in these other asset prices are likely to play an important role in how monetary policy is conducted. But what is the appropriate role for them to play? This paper answers this question by first surveying the monetary transmission mechanism through these other asset prices and then discusses their role in the conduct of monetary policy.

\section{I. \\ Asset Prices in the Monetary Transmission Mechanism}

In the literature on the monetary transmission mechanism, there are three categories of asset prices besides those on debt instruments that are viewed as providing important channels through which monetary policy affects the economy: 1) stock market prices, 2) real estate prices, and 3) exchange rates.

\section{Stock Market Prices}

Fluctuations of the stock market, which are influenced by monetary policy, have important impacts on the aggregate economy. Transmission mechanisms involving the stock market are of three types: 1) stock market effects on investment, 2) firm balance-sheet effects, 3) household wealth effects and 4) household liquidity effects.

Stock Market Effects on Investment. Tobin's q-theory (Tobin, 1969) provides an important mechanism for how movements in stock prices can affect the economy. Tobin's q is defined as the market value of firms divided by the replacement cost of capital. If $q$ is high, the market price of firms is high relative to the replacement cost of capital, and new plant and equipment capital is cheap relative to the market value of firms. Companies can then issue stock and get a high price for it relative to the cost of the facilities and equipment they are buying. 
Investment spending will rise because firms can now buy a lot of new investment goods with only a small issue of stock.

The crux of the Tobin q-model is that a link exists between stock prices and investment spending. But how might monetary policy affect stock prices? Expansionary monetary policy which lowers interest rates makes bonds less attractive relative to stocks and results in increased demand for stocks that bids up their price. Combining this with the fact that higher stock prices will lead to higher investment spending, leads to the following transmission mechanism of monetary policy which can be described by the following schematic:

$$
\mathrm{M} \uparrow \Rightarrow \mathrm{Ps} \uparrow=>\mathrm{q} \uparrow \Rightarrow \mathrm{I} \uparrow \Rightarrow \mathrm{Y} \uparrow
$$

where $\mathrm{M} \uparrow$ indicates expansionary monetary policy, leading to a rise in stock prices $\left(\mathrm{P}_{\mathrm{s}} \uparrow\right)$, which raises $q(q \uparrow)$, which raises investment $(I \uparrow)$, thereby leading to an increase in aggregate demand and a rise in output $(\mathrm{Y} \uparrow)$.

Another way of getting to this same mechanism is by recognizing that firms not only finance investment through bonds but by issuing equities (common stock). When stock prices rise, it now becomes cheaper for firms to finance their investment because each share that is issued produces more funds. Thus a rise in stock prices leads to increased investment spending. Therefore, an alternative description of this mechanism is that expansionary monetary policy (M $\uparrow$ ) which raises stock prices $\left(P_{s} \uparrow\right)$ lowers the cost of capital (c $\left.\downarrow\right)$ and so causes investment and output to rise $(\mathrm{I} \uparrow, \mathrm{Y} \uparrow){ }^{1}$ In other words:

$$
\mathrm{M} \uparrow=\mathrm{P} \uparrow \uparrow \Rightarrow \mathrm{c} \downarrow \Rightarrow \mathrm{I} \uparrow \Rightarrow \mathrm{Y} \uparrow
$$

Firm Balance-Sheet Effects. The presence of asymmetric information problems in credit markets provides another transmission mechanism for monetary policy that operates through

\footnotetext{
${ }^{1}$ See Bosworth (1975) and Hayashi (1982) for a demonstration that this alternative description of the link between stock prices and investment is equivalent to the Tobin's q approach.
} 
stock prices. This mechanism is often referred to as the "credit view", and it works through the effect of stock prices on firms's balance sheets so it is also referred to as the balance-sheet channel. ${ }^{2}$

The lower the net worth of business firms, the more severe is the adverse selection and moral hazard problems in lending to these firms. Lower net worth means that there is effectively less collateral for the loans made to a firm and so potential losses from adverse selection are higher. A decline in net worth, which increases the severity of the adverse selection problem, thus leads to decreased lending to finance investment spending. The lower net worth of business firms also increases the moral hazard problem because it means that owners of firms have a lower equity stake, giving them greater incentives to engage in risky investment projects. Since taking on riskier investment projects makes it more likely that lenders will not be paid back, a decrease in net worth leads to a decrease in lending and hence in investment spending.

Monetary policy can affect firms balance sheets and aggregate spending through the following mechanism. Expansionary monetary policy $(\mathrm{M} \uparrow)$ which causes a rise in stock prices $\left(\mathrm{P}_{\mathrm{S}} \uparrow\right)$ along lines described earlier, raises the new worth of firms $(\mathrm{NW} \uparrow)$, which reduces adverse selection and moral hazard problems, and so leads to higher lending ( $\mathrm{L} 1$ ). Higher lending then leads to higher investment spending ( $\mathrm{I} \uparrow$ ) and aggregate spending $(\mathrm{Y} \uparrow)$. This leads to the following schematic for this balance-sheet channel of monetary transmission.

$$
\mathrm{M} \uparrow \Rightarrow \mathrm{P}_{\mathrm{s}} \uparrow \Rightarrow \mathrm{NW} \uparrow \Rightarrow \mathrm{L} \uparrow \Rightarrow \mathrm{I} \uparrow \Rightarrow \mathrm{Y} \uparrow
$$

Household Liquidity Effects. Another way of looking at balance-sheet channels of monetary transmission is to look at household balance sheets, particularly liquidity effects on consumer durable and housing expenditures. ${ }^{3}$ In the liquidity effects view, balance sheet effects work through their impact on consumer's desire to spend rather than on lender's desire to lend.

\footnotetext{
${ }^{2}$ For surveys on the credit view, see Bernanke and Gertler (1995), Cecchetti (1995) Hubbard $(1995,2001)$ and Bernake, Gertler and Gilchrist (1999).

${ }^{3}$ See Mishkin $(1976,1977)$.
} 
Because of asymmetric information about their quality, consumer durables and housing are very illiquid assets. If, as a result of a bad income shock, consumers needed to sell their consumer durables or housing to raise money, they would expect a big loss because they could not get the full value of these assets in a distress sale. In contrast, if consumers held financial assets (such as money in the bank, stocks, or bonds), they could easily sell them quickly for their full market value and raise the cash. Hence if consumers expect a higher likelihood of finding themselves in financial distress, they would rather be holding fewer illiquid consumer durable or housing assets and more liquid financial assets.

A consumer's balance sheet should be an important influence on his or her estimate of the likelihood of suffering financial distress. Specifically, when consumers have a large amount of financial assets relative to their debts, their estimate of the probability of financial distress is low, and they will be more willing to purchase consumer durables or housing. When stock prices rise, the value of financial assets rises as well; consumer durable expenditure will also rise because consumers have a more secure financial position and a lower estimate of the likelihood of suffering financial distress. This leads to another transmission mechanism for monetary policy, operating through the link between money and stock prices:

$$
\begin{gathered}
\mathrm{M} \uparrow \Rightarrow \mathrm{P}_{s} \uparrow \Rightarrow \text { Financial Assets } \uparrow \Rightarrow \\
\text { Likelihood of Financial Distress } \downarrow \Rightarrow>C_{d} \uparrow, H \uparrow=>Y \uparrow
\end{gathered}
$$

where $\mathrm{C}_{\mathrm{d}} \uparrow$ indicates a rise in consumer durable expenditure and $\mathrm{H} \uparrow$ a rise in residential housing spending.

Household Wealth Effects. Another balance-sheet channel operating through consumer involves household wealth effects. Modigliani's life cycle model states that consumption is determined by the lifetime resources of consumers. An important component of consumers' lifetime resources is their financial wealth, a major component of which is common stocks. Thus expansionary monetary policy which raises stock prices, raises the value of household wealth, thereby increasing the lifetime resources of consumers, which causes consumption to rise. This 
produces the following transmission mechanism:

$$
\mathrm{M} \uparrow=>\mathrm{P}_{\mathrm{s}} \uparrow \Rightarrow \mathrm{W} \uparrow \Rightarrow \mathrm{C} \uparrow \Rightarrow \mathrm{Y} \uparrow
$$

where $\mathrm{W} \uparrow$ and $\mathrm{C} \uparrow$ indicate household wealth and consumption rises. Research has found this transmission mechanism to be quite strong in the United States, but the size of the wealth effect is still controversial. ${ }^{4}$

\section{Real Estate Prices}

Another set of asset prices that play an important role in the monetary transmission mechanism are real estate prices. Real estate prices can affect aggregate demand through three routes: 1) direct effects on housing expenditure, 2) household wealth, and 3) bank balance sheets.

Direct Effects on Housing Expenditure. Monetary expansion ( $\mathrm{M} \uparrow$ ), which lowers interest rates, lowers the cost of financing housing and so increases their price $\left(\mathrm{P}_{h} \uparrow\right)$. With a higher price of housing relative to its construction cost, construction firms find it more profitable to build housing, and thus housing expenditure will rise $(\mathrm{H} \uparrow)$ and so aggregate demand will rise $(\mathrm{Y} \uparrow)^{5}$ This transmission mechanism is then described by the following schematic.

$$
\mathrm{M} \uparrow=>\mathrm{P}_{\mathrm{h}} \uparrow \Rightarrow \mathrm{H} \uparrow \Rightarrow \mathrm{Y} \uparrow
$$

Household Wealth Effects. Housing prices are an important component of household

\footnotetext{
${ }^{4}$ See Modigliani (1971) and Lettau, Ludvigson and Steindel (2001).

${ }^{5}$ This model of housing expenditure is really a variant of Tobin's q-theory in which q for housing investment is the price of housing relative to its replacement cost. For a recent empirical analysis of a model of this type, see McCarthy and Peach (2001).
} 
wealth, which as we have see, affects consumption spending. Hence, expansionary monetary policy $(\mathrm{M} \uparrow)$ which raises housing prices $\left(\mathrm{P}_{h} \uparrow\right)$, also raises household wealth $(\mathrm{W} \uparrow)$, which raises consumption spending $(\mathrm{C} \uparrow)$ and aggregate demand $(\mathrm{Y} \uparrow)$ : i.e.,

$$
\mathrm{M} \uparrow \Rightarrow \mathrm{Ph} \uparrow \Rightarrow \mathrm{W} \uparrow=\mathrm{C} \uparrow \Rightarrow \mathrm{Y} \uparrow
$$

Bank Balance Sheets. The credit view of the monetary transmission mechanism suggest that banks play a special role in the financial system because they are especially well suited to solve asymmetric information problems in credit markets. Certain borrowers will then not have access to the credit markets unless they borrow from banks. ${ }^{6}$ Banks engage in a substantial amount of real estate lending, in which the value of the real estate acts as collateral. If real estate prices rise as a result of monetary expansion, then banks loan losses will decrease, which increases their bank capital. Higher bank capital then allows banks to engage in more lending, and because banks are special with many customers dependent on them, investment and aggregate demand will rise. The bank balance-sheet channel thus can be described as follows:

$$
\mathrm{M} \uparrow \Rightarrow \mathrm{Pr} \uparrow \Rightarrow \mathrm{NW}_{\mathrm{b}} \uparrow=\mathrm{L} \uparrow \Rightarrow \mathrm{I} \uparrow \Rightarrow \mathrm{Y} \uparrow
$$

where expansionary monetary policy $(\mathrm{M} \uparrow)$ which raises real estate prices $\left(\mathrm{P}_{\mathrm{r}} \uparrow\right)$, raises bank capital $\left(\mathrm{NW}_{\mathrm{b}} \uparrow\right)$ and causes bank lending to rise $(\mathrm{L} \uparrow)$, thereby causing investment and output to rise ( $\mathrm{I} \uparrow$ and $\mathrm{Y} \uparrow$ ).

When, the opposite happens and real estate prices fall, this transmission mechanism has often been described as a "capital crunch" and was operational in the United States in the early 1990s (Bernanke and Lown, 1991) and has been an important source of stagnation in Japan in recent years.

\footnotetext{
${ }^{6}$ See Kashyap and Stein (1994) and Gertler and Gilchrist (1994).
} 


\section{Exchange Rates}

There are two primary mechanisms that operate through exchange rates: 1) exchange rate effects on net exports and 2) exchange rate effects on balance sheets.

Exchange Rate Effects on Net Exports. With the growing internationalization of economies throughout the world and the advent of flexible exchange rates, more attention has been paid to how monetary policy affects exchange rates, which in turn affect net exports and aggregate output. Clearly this channel does not operate if a country has a fixed exchange rate, and the more open an economy is, the stronger is this channel.

Expansionary monetary policy affects exchange rates because when it leads to a fall in domestic interest rates, deposits denominated in domestic currency become less attractive relative to deposits denominated in foreign currencies. As a result, the value of domestic deposits relative to other currency deposits falls, and the exchange rate depreciates (denoted by $\mathrm{E}$ 1). ${ }^{7}$ The lower value of the domestic currency makes domestic goods cheaper than foreign goods, thereby causing a rise in net exports $(\mathrm{NX} \uparrow)$ and hence in aggregate spending $(\mathrm{Y} \uparrow)$. The schematic for the monetary transmission mechanism that operates through the exchange rate is:

$$
\mathrm{M} \uparrow \Rightarrow \mathrm{E} \downarrow \Rightarrow \mathrm{NX} \uparrow \Rightarrow \mathrm{Y} \uparrow
$$

Exchange Rate Effects on Balance Sheets. Fluctuations in exchange rates also can have important effects on aggregate demand by affecting the balance sheets of both financial and nonfinancial firms when a substantial amount of domestic debt is denominated in foreign currency, which is the case for most emerging market countries. In these countries, monetary expansion often can have a negative impact on aggregate demand if it leads to a depreciation of

\footnotetext{
${ }^{7}$ In the literature, a depreciation of the currency is typically denoted as e 1 , but I have used the notation $\mathrm{E} \downarrow$ because $\mathrm{I}$ think it is more intuitive.
} 
the exchange rate through the following mechanism.

With debt contracts denominated in foreign currency, expansionary monetary policy (M 1) which leads to a depreciation or devaluation of the domestic currency $(E \downarrow)$ results in the debt burden of domestic nonfinancial firms to increase. Since assets are typically denominated in domestic currency and so do not increase in value, there is a resulting decline in net worth (NW ๖). This deterioration in balance sheets then increases adverse selection and moral hazard problems, which as discussed above, leads to a decline in lending ( $\mathrm{L} \downarrow$ ), a decline in investment $(\mathrm{I} \downarrow)$ and hence in economic activity (Y $\downarrow$ ). The schematic for this transmission mechanism is as follows:

$$
\mathrm{M} \uparrow \Rightarrow \mathrm{E} \downarrow \Rightarrow \mathrm{NW} \downarrow \Rightarrow \mathrm{L} \downarrow \Rightarrow \mathrm{I} \downarrow \Rightarrow \mathrm{Y} \downarrow
$$

This mechanism was very important in the recent financial crises in Mexico and East Asia. ${ }^{8}$ For example, this mechanism was particularly strong in Indonesia, the worst hit of all the crisis countries, which saw the value of its currency decline by over 75 percent, thus increasing the rupiah value of foreign-denominated debt by a factor of four. Even a healthy firm is likely to be driven into insolvency by such a shock if it had a significant amount of foreign-denominated debt, and then no one will lend to it even if it has productive investment opportunities.

A second mechanism through which an exchange rate depreciation can lead to a decline in aggregate demand in emerging markets operates through deterioration of bank balance sheets. For example, in Mexico and the East Asian countries, banks and many other financial institutions had many liabilities denominated in foreign currency, which increased sharply in value when a depreciation occurred. Ont he other hand, the problems of firms and households meant that they were unable to pay off their debt, also resulting in loan losses on the asset side of financial institutions' balance sheets. The result was that banks' and other financial institutions' balance sheets were squeezed from both the assets and liabilities side. Moreover, many of these institutions foreign-currency denominated debt was very short term, so that the sharp increase in

\footnotetext{
${ }^{8}$ For example, see Mishkin (1996, 1999a).
} 
the value of this debt led to liquidity problems because this debt needed to be paid back quickly. The result of the further deterioration in banks' and other financial institutions' balance sheets and their weakened capital base is that they cut back lending. In the case of Indonesia, these forces were severe enough to cause a banking panic in which numerous banks were forced to go out of business.

The effect of depreciations on bank balance sheets implies that expansionary monetary policy $(\mathrm{M} \uparrow)$ may actually be contractionary in emerging market countries by causing bank balance sheets to deteriorate ( $\left.\mathrm{NW}_{\mathrm{b}} \downarrow\right)$ ), bank lending to fall ( $\mathrm{L} \downarrow$ ), which then causes investment and aggregate output to fall ( $\mathrm{I} \downarrow$ and $\mathrm{Y} \downarrow$ ): i.e.,

$$
\mathrm{M} \uparrow \Rightarrow \mathrm{E} \downarrow \Rightarrow \mathrm{NW}_{\mathrm{b}} \downarrow \Rightarrow \mathrm{L} \downarrow \Rightarrow \mathrm{I} \downarrow \Rightarrow \mathrm{Y} \downarrow
$$

It is important to note that the possible contractionary effects from expansionary monetary policy operating through exchange rate effects on balance sheets only operate if the economy has a substantial amount of debt denominated in foreign currency. These mechanisms are thus rarely important in industrialized countries whose debt is typically denominated in domestic currency, but they can be very important in emerging market countries whose debt structure may be entirely different, with much of the debt denominated in foreign currency.

\section{II. The Role of Asset Prices in Monetary Policy}

The survey in the previous section suggests that monetary policy works not just through its direct effects on interest rates, but also through its effects on other asset prices. Since other asset prices are an important element of the monetary transmission mechanism, how can 
monetary policymakers incorporate movements of these asset prices into their decisions about the conduct of monetary policy?

In looking at the role of asset prices in monetary policy, it is worth separating the discussion into how central banks might respond to exchange rates and how they might respond to fluctuations in stock market and real estate prices.

\section{Exchange Rates}

The asset price that typically receives the most attention in discussions of monetary policy is the exchange rate. Central bank's clearly care about the value of the domestic currency for several reasons. Changes in the exchange rate can have a major impact on inflation, particularly in small, open economies. For example, depreciations lead to a rise in inflation as a result of the pass-through from higher import prices and greater demand for net exports, as discussed in the previous section. In addition, the public and politicians pay attention to the exchange rate and this puts pressure on the central bank to alter monetary policy. An appreciation of the domestic currency can make domestic businesses uncompetitive, while a depreciation is often seen as a failure of the central bank, as has recently been the case for the European Central Bank, which has been blamed, I think unfairly, for the euro's decline.

Emerging market countries, quite correctly, have an even greater concern about exchange rate movements. Not only can a real appreciation make domestic industries less competitive, but it can lead to large current account deficits which might make the country more vulnerable to currency crisis if capital inflows turn to outflows. Depreciations in emerging market countries are particularly dangerous because they can be contractionary, as described in the previous section, and can trigger a financial crisis along the lines suggested in Mishkin $(1996,1999)$.

Concern about exchange rate fluctuations might lead countries to choose to peg their exchange rates to that of another country. In other work, I have discussed the pros and cons of pegging exchange rates as a monetary policy strategy and I will not discuss this issue further. ${ }^{9}$

\footnotetext{
${ }^{9}$ See Mishkin (1999b) and Mishkin and Savastano (2001).
} 
However, if a country decides that it wants to have its own independent monetary policy, then with open capital markets it has to allow the exchange rate to fluctuate. However, the fact that exchange rate fluctuations are a major concern in so many countries raises the danger that monetary policy may put too much focus on limiting exchange rate movements. This indeed was a problem for Israel in the early stages of its inflation targeting regime. As part of this regime, Israel had an intermediate target of an exchange rate band around a crawling peg, whose rate of crawl was set in a forward-looking manner by deriving it from the inflation target for the coming year. Even though the Bank of Israel downplayed the exchange rate target relative to the inflation target over time, it did slow the Bank's effort to win support for disinflation and lowering of the inflation targets (e.g., see Bernanke, Laubach, Mishkin and Posen, 1999.)

The second problem from a focus on limiting exchange rate fluctuations is that it can induce the wrong policy response when a country if faced with real shocks such as a terms of trade shock. Two graphic examples occurred in New Zealand and Chile in the late 1990s.

Because of the direct impact of exchange rates on inflation, the Reserve Bank of New Zealand tended to focus on the exchange rate as an indicator of the monetary policy stance. By early 1997, the Reserve Bank institutionalized this focus by adopting as its primary indicator of monetary policy a Monetary Conditions Index (MCI) similar to that developed by the Bank of Canada. The idea behind the MCI, which is a weighted average of the exchange rate and a shortterm interest rate, is that both interest rates and exchange rates on average have offsetting impacts on inflation. When the exchange rate falls, this usually leads to higher inflation in the future, and so interest rates need to rise to offset the upward pressure on inflation. However, the offsetting effects of interest rates and exchange rates on inflation depend on the nature of the shocks to the exchange rates. If the exchange rate depreciation comes from portfolio considerations, then it does lead to higher inflation and the optimal response is an interest rate rise. However, if the reason for the exchange rate depreciation is a real shock such as a negative terms of trade shock which decreases the demand for a country's exports, then the situation is entirely different. The negative terms of trade shock reduces aggregate demand and is thus likely to be deflationary. The correct interest rate response is then a decline in interest rates, not a rise as the MCI suggests. With the negative terms of trade shock in 1997, the adoption of the MCI in 1997 led to 
exactly the wrong monetary policy response to East Asian crisis. With depreciation setting in after the crisis began in July 1997 after the devaluation of the Thai baht, the MCI began a sharp decline, indicating that the Reserve Bank needed to raise interest rates, which it did by over 200 basis points. The result was very tight monetary policy, with the overnight cash rate exceeding 9\% by June of 1998 . Because the depreciation was due to a substantial, negative terms of trade shock which decreased aggregate demand, the tightening of monetary policy, not surprisingly, lead to a severe recession and an undershoot of the inflation target range with actual deflation occurring in 1999. ${ }^{10}$ The Reserve Bank of New Zealand did eventually realize its mistake and reversed course, sharply lowering interest rates beginning in July 1998 after the economy had entered a recession, but by then it was too late. It also recognized the problems with using an MCI as an indicator of monetary policy and abandoned it in 1999. Now the Reserve Bank operates monetary policy in a more conventional way, using the overnight cash rate as its policy instrument, with far less emphasis on the exchange rate in its monetary policy decisions.

Chile, which also adopted inflation targeting in the early 1990s, also included a focus on limiting exchange rate fluctuations by having an exchange rate band with a crawling peg which was (loosely) tied to lagged domestic inflation. ${ }^{11}$ This focus on the exchange rate induced a serious policy mistake in 1998 because the central bank was afraid it might lose credibility in the face of the financial turmoil if it allowed the exchange rate to depreciate after what had taken place in financial markets after the East Asian crisis and the Russian meltdown, Thus instead of easing monetary policy in the face of the negative terms of trade shock, the central bank raised interest rates sharply and even narrowed its exchange rate band. In hindsight, these decisions appear to have been a mistake: the inflation target was undershot and the economy entered a recession for the first time in the 1990s. With this outcome, the central bank came under strong

\footnotetext{
${ }^{10}$ The terms of trade shock, however, was not the only negative shock the New Zealand economy faced during that period. Its farm sector experienced a severe drought which also hurt the economy. Thus, a mistake in monetary policy was not the only source of the recession. Bad luck played a role too. See Drew and Orr (1999) and Brash (2000).

${ }^{11}$ See Landerretche, Morandé and Schmidt-Hebbel (1999), and Mishkin and Savastano (2001).
} 
criticism for the first time since it had adopted its inflation targeting regime in 1990, weakening support for the independence of the central bank and its inflation targeting regime. During 1999, the central bank did reverse course, easing monetary policy by lowering interest rates and allowing the peso to decline.

The contrast of the experience of New Zealand and Chile during this period with that of Australia, another small open economy with an inflation targeting regime is striking. Prior to adoption of their inflation targeting regime in 1994, the Reserve Bank of Australia had adopted a policy of allowing the exchange rate to fluctuate without interference, particularly if the source of the exchange rate change was a real shock, like a terms of trade shock. Thus when faced with the devaluation in Thailand in July 1997, the Reserve Bank recognized that it would face a substantial negative terms of trade shock because of the large component of its foreign trade conducted with the Asian region and thus decided that it would not fight the depreciation of the Australian dollar that would inevitably result. ${ }^{12}$ Thus in contrast to New Zealand, it immediately lowered the overnight cash rate by 50 basis points to $5 \%$ and kept it near at this level until the end of 1998, when it was lowered again by another 25 basis points.

Indeed, the adoption of the inflation targeting regime probably helped the Reserve Bank of Australia to be even more aggressive in its easing in response to the East Asian crisis and helps explain why their response was so rapid. The Reserve Bank was able to make clear that easing was exactly what inflation targeting called for in order to prevent an undershooting of the target, so that the easing was unlikely to have an adverse effect on inflation expectations. The outcome of the Reserve Bank's policy actions was extremely favorable. In contrast to New Zealand and Chile, real output growth remained strong throughout this period. Furthermore, there were no negative consequences for inflation despite the substantial depreciation of the Australian dollar against the U.S. dollar by close to $20 \%$ : inflation remained under control, actually falling during this period to end up slightly under the target range of 2 to $3 \%$.

The analysis above and the recent experiences of countries like New Zealand, Chile and Australia strongly suggest that central banks' concerns about the exchange rate is not a reason for

\footnotetext{
${ }^{12}$ See MacFarlane (1999) and Stevens (1999).
} 
them to stop keeping their eyes on the inflation ball.

Is a focus on achieving the inflation goal inconsistent wth central banks paying some attention to the exchange rate? Of course not. As we have seen in the previous section, an important transmission mechanism for monetary policy is the exchange rate and its level has important effects on inflation and aggregate demand depending on the nature of the shocks, particularly in small, open economies. Therefore, central banks will closely monitor exchange rate developments and factor them into its decisions on setting monetary policy instruments. A depreciation of the exchange rate due to portfolio shocks like terms of trade shocks requires a tightening of monetary policy in order to keep inflation from rising. On the other hand, a depreciation when there is a negative terms of trade shock requires a different response, an easing of monetary policy as Australia did in 1997.

Does the avoidance of a target for the exchange rate imply a policy of benign neglect of exchange rates. This issue is particularly relevant for emerging market countries as is emphasized in Mishkin (2000) and Mishkin and Savastano (2001). For the reasons discussed earlier, emerging market countries with a lot of foreign-denominated debt may not be able to afford sharp depreciations of their currencies which can destroy balance sheets and trigger a sharp fall in aggregate demand. Central banks in these countries may thus have to smooth "excessive" exchange rate fluctuations, while making it clear to the public that they will not preclude the exchange rate from reaching its market-determined level over longer horizons. The stated rationale for exchange rate smoothing is similar to that of interest-rate smoothing, which is practiced by most central banks, even those engaged in inflation targeting: the policy is not aimed at resisting market-determined movements in an asset price, but at mitigating potentially destabilizing effects of abrupt changes in that price.

\section{Stock and Real Estate Prices}

With the bursting of the stock market and real estate bubble in Japan at the beginning of the 1990s and the recent stock market boom (and partial reversal) in the United States, there has 
been a growing debate about how the monetary authorities might best react to stock market and real estate fluctuations. ${ }^{13}$ This section will argue that the reaction to these asset prices raises similar issues to the reaction to exchange rate fluctuations. Improved economic performance will result if the policy response depends on the nature of the shocks, while the central bank is not be perceived as having a target for any asset price, whether it is an exchange rate, or stock market or real estate prices.

The discussion of the monetary transmission mechanism in the previous section indicates that real estate and stock price movement do have an important impact on aggregate demand and thus must be followed closely to evaluate the stance of monetary policy. Indeed, with a standard loss function in which the central bank minimizes a weighted average of squared deviations of inflation from its target level and output from potential output, optimal monetary policy will react to changes in real estate and stock market prices. However, depending on the nature of the shock to these prices, and depending on whether the shock is considered to be temporary or permanent, the optimal response of monetary policy would differ. Thus, just as targets for exchange rates would be problematic, so too would targets for real estate and stock prices.

But this still begs the question of whether monetary authorities can improve their performance by trying to prick asset price bubbles, because subsequent collapses of these asset prices might be highly damaging to the economy, as they were in Japan in the 1990s. Cecchetti, Genburg, Lipsky and Wadhwani (1999), for example, argue that central banks should at times target asset prices in order to stop bubbles from getting too far out of hand. However, there as serious flaws in their argument. First is that it is very hard for monetary authorities to identify that a bubble has actually developed. To assume that they can is to assume that the monetary authorities have better information and predictive ability than the private sector. If the central bank has no informational advantage, then if it knows that a bubble has developed that will eventually crash, then the market knows this too and then the bubble would unravel and thus would be unlikely to develop. Without an informational advantage, the central bank is as likely

\footnotetext{
${ }^{13}$ For example, see Cecchetti, Genburg, Lipsky and Wadwani (1999) and Bernanke and Gertler (1999).
} 
to mispredict the presence of a bubble as the private market and thus will frequently be mistaken, thus frequently pursuing the wrong monetary policy. Cecchetti, Genburg, Lipski and Wadhwani (1999) find favorable results in their simulations when the central bank conducts policy to prick asset price bubble because they assume that the central bank knows the bubble is in progress. This assumption is highly dubious because it is hard to believe that the central bank has this kind of informational advantage over private markets. Indeed, the view that government officials know better than the markets has been proved wrong over and over again.

A second problem with the central bank targeting stock prices is that it is likely to make the central bank look foolish. The linkage between monetary policy and stock prices, although an important part of the transmission mechanism, is still nevertheless, a weak one. Most fluctuations in stock prices occur for reasons unrelated to monetary policy, either reflecting real fundamentals or animal spirits. The loose link between monetary policy and stock prices therefore means that the ability of the central bank to control stock prices is very limited. Thus, if the central bank indicates that it wants stock prices to change in a particular direction, it is likely to find that stock prices may move in the opposite direction, thus making the central bank look inept. Recall that when Alan Greenspan made his speech in 1997 suggesting that the stock market might be exhibiting "irrational exuberance", the Dow Jones average was around 6500. This didn't stop the market from rising, with the Dow subsequently climbing to above 11000.

An additional problem with targeting asset prices is that it may weaken support for a central bank because it looks like it is trying to control too many elements of the economy. Part of the recent successes of central banks throughout the world has been that they have narrowed their focus and have more actively communicated what they can and cannot do. Specifically, central banks have argued that they are less capable of managing short-run business cycle fluctuation and should therefore focus more on price stability as their primary goal. A key element of the success of the Bundesbank's monetary targeting regime was that it did not focus on short-run output fluctuation in setting its monetary policy instruments. ${ }^{14}$ This communication strategy for the Bundesbank has been very successful, as pointed out in Bernanke, Laubach,

\footnotetext{
${ }^{14}$ See Bernanke, Laubach, Mishkin and Posen (1999).
} 
Mishkin and Posen (1999), has been adopted as a key element in inflation targeting, a monetary regime that has been gaining in popularity in recent years. By narrowing their focus, central banks in recent years have been able to increase public support for their independence. ${ }^{15}$ Extending their focus to asset prices has the potential to weaken public support for central banks and may even cause the public to worry that the central bank is too powerful, having undue influence over all aspects of the economy.

\section{III. Conclusions}

The discussion in this paper shows that other asset prices, and not just interest rates, are important elements of the monetary transmission mechanism. This provides a rationale for why monetary authorities pay a lot of attention to these other asset prices in the conduct of monetary policy. However, this paper has also argued that targeting other asset prices, whether they are exchange rates, real estate or stock market prices, is likely to worsen the performance of monetary policy. This is because the response of monetary policy to asset price fluctuations depends on the nature of the shocks to asset prices and the degree of permanence of the shocks. Furthermore, targeting asset prices is likely to erode support for the independence of central banks because control of these asset prices is beyond central banks' capabilities.

\footnotetext{
${ }^{15}$ See Mishkin (1999b) and Bernanke, Laubach, Mishkin and Posen (1999).
} 


\section{References}

Bernanke, Ben S., Thomas. Laubach, Frederic S. Mishkin, and Adam S. Posen, 1999, Inflation

Targeting: Lessons from the International Experience, Princeton, NJ: Princeton University Press.

Bernanke, Ben S., and Mark Gertler, 1995. "Inside the Black Box: The Credit Channel of Monetary Policy Transmission," Journal of Economic Perspectives, Fall, 9, 27-48.

Bernanke, Ben S. and Mark Gertler, 1999. "Monetary Policy and Asset Price Volatility," in New Challenges for Monetary Policy, Federal Reserve Bank of Kansas City: Kansas City.

Bernanke, Ben S., Mark Gertler and Simon Gilchrist, 1999. "The Financial Accelerator in a Quantitative Business Cycle Framework," in John Taylor and Michael Woodford, eds., Handbook of Macroeconomics, vol. 10 (Elsevier: Amsterdam): 1341-1393.

Bernanke, B.S. and C. Lown. 1991. "The Credit Crunch," Brookings Papers on Economic Activity, 2, pp. 205-39.

Bosworth, Barry, 1975. "The Stock Market and the Economy," Brookings Papers on Economic Activity 2, 257-90.

Brash, Donald T. 2000. "Inflation Targeting in New Zealand, 1988-2000," Speech to the TransTasman Business Cycle, Melbourne, February 9.

Cecchetti, Stephen G., 1995. "Distinguishing Theories of the Monetary Transmission Mechanism," Federal Reserve Bank of St. Louis Review, May/June, 77, 83-97.

Cecchetti, Stephen G., Hans Genburg, John Lipski and Sushil Wadhwani, 2000. Asset Prices and 
Central Bank Policy, Geneva Reports on the World Economy (International Center for Monetary and Banking Studies and Centre for Economic Policy Research, London).

Drew, Aaron and Adrian Orr, 1999. "The Reserve Bank's Role in the Recent Business Cycle: Actions and Evolution," Reserve Bank of New Zealand Bulletin, 62, No. 1.

Gertler, Mark and Simon Gilchrist, 1994. "Monetary Policy, Business Cycles and the Behavior of Small Manufacturing Firms," Quarterly Journal of Economics 109, 309-340.

Hayashi, Fumio, 1982. "Tobin's Marginal q and Average q: A Neoclassical Interpretation," Econometrica, vol. 50,\#1: 213-24.

Hubbard, R. Glenn, 1995. "Is There a "Credit Channel" for Monetary Policy?", Federal Reserve Bank of St. Louis Review, May/June, 77, 63-74.

Hubbard, R. Glenn, 2001, "Capital Market Imperfections, Investment, and the Monetary Transmission Mechanism," in Deutsche Bundesbank, ed., Investing Today for the World of Tomorrow (Springer-Verlag: New York): 165-194.

Kashyap, Anil K. and Jeremy C. Stein. 1994. "Monetary Policy and Bank Lending," in N.G. Mankiw, ed., Monetary Policy (University of Chicago Press; Chicago).

Landerretche, O., F. Morandé and K. Schmidt-Hebbel, 1999, "Inflation Targets and Stabilization in Chile," Central Bank of Chile, Working Paper 55, December

Lettau, Martin, Ludvigson, Sydney and Charles Steindel, 2001. "Monetary Policy Transmission Through the Consumption-Wealth Channel," forthcoming in Federal Reserve Bank of New York, Economic Policy Review, Conference on Financial Innovation and Monetary Transmission. 
Macfarlane, Ian J. 1999. "Statement to Parliamentary Committee," in Reserve Bank of Australia Bulletin, January: 16-20.

McCarthy, Jonathan and Richard W. Peach, 2001. "Monetary Policy Transmission to Residential Investment," forthcoming in Federal Reserve Bank of New York, Economic Policy Review, Conference on Financial Innovation and Monetary Transmission.

Mishkin, Frederic S. 1976. "Illiquidity, Consumer Durable Expenditure, and Monetary Policy," American Economic Review, 66 No. 4 (September): 642-654.

Mishkin, Frederic S. 1977. "What Depressed the Consumer? The Household Balance-Sheet and the 1973-75 Recession," Brookings Paper on Economic Activity 1: 123-164.

Mishkin, Frederic S., 1996. "Understanding Financial Crises: A Developing Country Perspective," in Michael Bruno and Boris Pleskovic, eds., Annual World Bank Conference on Development Economics, World Bank, Washington D.C.: 29-62.

Mishkin, Frederic S., 1999a. "Lessons from the Asian Crisis," Journal of International Money and Finance, 18, 4: 709-723.

Mishkin, Frederic S. 1999b. "International Experiences with Different Monetary Policy Regimes," Journal of Monetary Economics, Vol. 43, \#3: 579-606.

Mishkin, Frederic S. 2000. "Inflation Targeting in Emerging Market Countries," American Economic Review (May), Vol. 90, \#2.

Mishkin, F. and M. Savastano, 2001. "Monetary Policy Strategies for Latin America," Journal of Development Economics, forthcoming October. 
Franco Modigliani, 1971. "Monetary Policy and Consumption," in Consumer Spending and Monetary Policy: The Linkages, Boston: Federal Reserve Bank of Boston, 9-84.

Stevens, Glenn R. 1999. "Six Years of Inflation Targeting," Reserve Bank of Australia Bulletin, May: 46-61.

James Tobin, 1969. "A General Equilibrium Approach to Monetary Theory," Journal of Money, Credit, and Banking, February, 1, 15-29. 